\title{
Female genital mutilation/cutting: A review of laws and policies in Kenya and Nigeria
}

Samuel Kimani

Otibho Obianwu

Population Council

Follow this and additional works at: https://knowledgecommons.popcouncil.org/departments_sbsr-rh

Part of the Family, Life Course, and Society Commons, International Public Health Commons, Law and Gender Commons, and the Sociology of Culture Commons How does access to this work benefit you? Let us know!

\section{Recommended Citation}

Kimani, Samuel and Otibho Obianwu. 2020. "Female genital mutilation/cutting: A review of laws and policies in Kenya and Nigeria," Evidence to End FGM/C: Research to Help Girls and Women Thrive. New York: Population Council. 


\section{Evidence to (\%)
End FGM/C}

Research to Help Girls and Women Thrive

\section{FEMALE GENITAL MUTILATION/CUTTING: \\ A REVIEW OF LAWS AND POLICIES IN KENYA AND NIGERIA}

June 2020 


\section{FEMALE GENITAL MUTILATION/CUTTING: A REVIEW OF LAWS AND POLICIES IN KENYA AND NIGERIA}

SAMUEL KIMANI AFRICA COORDINATING CENTRE FOR THE ABANDONMENT OF FEMALE GENITAL MUTILATION/CUTTING (ACCAF) UNIVERSITY OF NAIROBI

OTIBHO OBIANWU POPULATION COUNCIL

JUNE 2020 
Evidence to End FGM/C: Research to Help Girls and Women Thrive generates evidence to inform and influence investments, policies, and programmes for ending female genital mutilation/cutting in different contexts. Evidence to End FGM/C is led by the Population Council, Nairobi in partnership with the Africa Coordinating Centre for the Abandonment of Female Genital Mutilation/Cutting (ACCAF), Kenya; the Global Research and Advocacy Group (GRAG), Senegal; Population Council, Nigeria; Population Council, Egypt; Population Council, Ethiopia; MannionDaniels, Ltd. (MD); Population Reference Bureau (PRB); University of California, San Diego (Dr. Gerry Mackie); and University of Washington, Seattle (Prof. Bettina Shell-Duncan).

POPULATION COUNCIL

Ideas. Evidence. Impact.
The Population Council confronts critical health and development issues-from stopping the spread of HIV to improving reproductive health and ensuring that young people lead full and productive lives. Through biomedical, social science, and public health research in 50 countries, we work with our partners to deliver solutions that lead to more effective policies, programmes, and technologies that improve lives around the world. Established in 1952 and headquartered in New York, the Council is a nongovernmental, nonprofit organisation governed by an international board of trustees. www.popcouncil.org

ACCAF is based at the University of Nairobi, College of Health Sciences, a premier institution for training of health care professionals, and a leader in health research and community services. Our goals and objectives are to: strengthen capacity for FGM/C research in Africa, implement FGM/C interventions, and improve care for women and girls who have undergone $\mathrm{FGM} / \mathrm{C}$, monitor progress in the abandonment of $\mathrm{FGM} / \mathrm{C}$, and inform policy programming on $\mathrm{FGM} / \mathrm{C}$ issues. www.accaf.org

Suggested Citation: Kimani, Samuel and Obianwu, Otibho. 2020. "Female Genital Mutilation/Cutting: A Review of Laws and Policies in Kenya and Nigeria." Evidence to End FGM/C: Research to Help Girls and Women Thrive. New York: Population Council.

This is a working paper and represents research in progress. This paper represents the opinions of the authors and is the product of professional research. This paper has not been peer reviewed, and this version may be updated with additional analyses in subsequent publications.

Please address any inquiries about the Evidence to End FGM/C programme consortium to: pubinfo@popcouncil.org

Funded by:

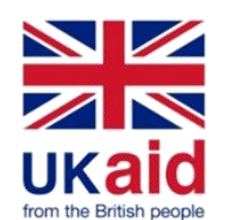

This document is output from a programme funded by UK Aid from the UK government for the benefit of developing countries. However, the views expressed and information contained in it are not necessarily those of, or endorsed by the UK government, which can accept no responsibility for such views or information or for any reliance placed on them. 


\section{Table of Contents}

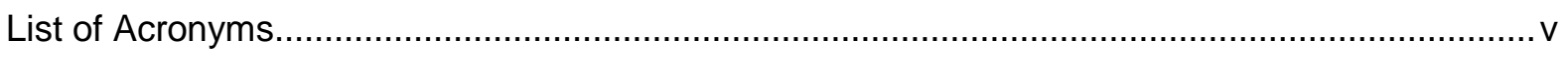

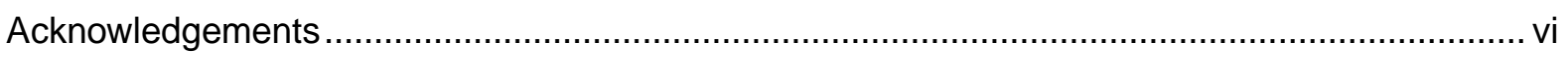

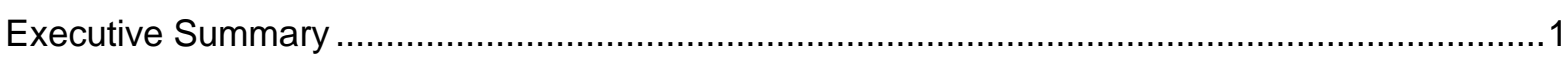

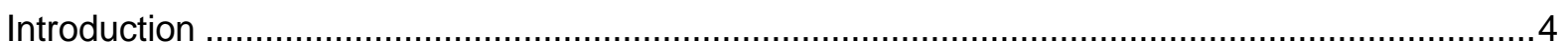

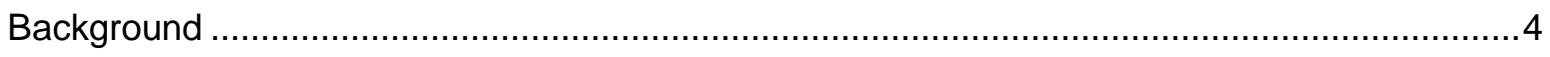

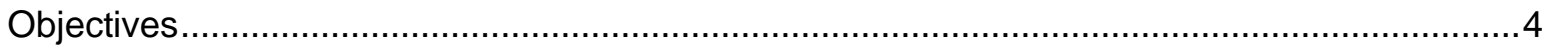

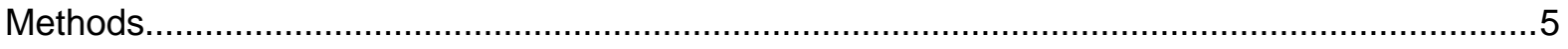

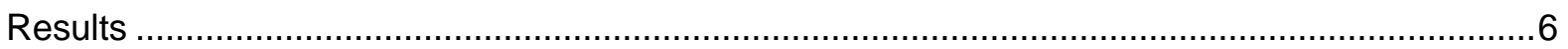

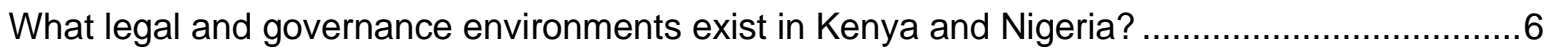

What laws address FGM/C prevention and response in Kenya and Nigeria? ..........................6

What are the policies that address FGM/C prevention and response in Kenya and Nigeria? .....9

What plans of action address FGM/C prevention and response in Kenya and Nigeria? ...........11

What guidelines address FGM/C prevention and management in Kenya and Nigeria?...........12

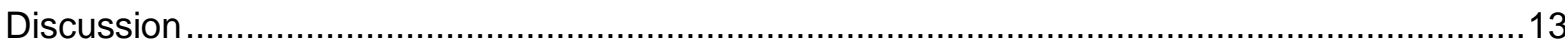

What can we learn from the FGM/C legal/policy analyses in Kenya and Nigeria? ..................14

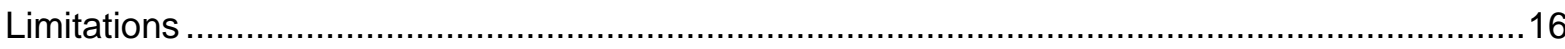

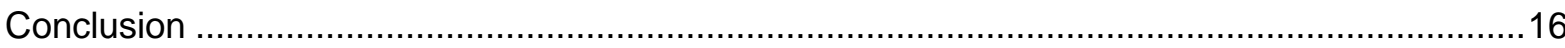

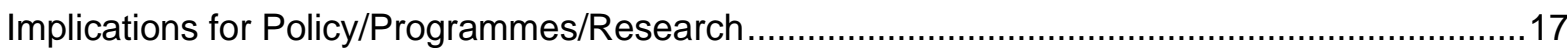

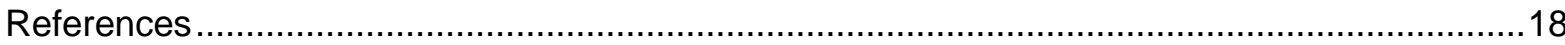

Attachment: Female Genital Mutilation/Cutting: A Review of Laws and Policies in Kenya and Nigeria Report Appendices 


\section{List of Acronyms}

ASRH Adolescent Sexual and Reproductive Health

CEDAW Convention on the Elimination of all Forms of Discrimination Against Women

FGM/C Female Genital Mutilation/Cutting

FMOH Federal Ministry of Health (Nigeria)

HMIS Health Management Information System (Kenya)

KNBS Kenya National Bureau of Statistics

M\&E Monitoring and Evaluation

NGO Nongovernmental Organisation

NHMIS National Health Management Information System (Nigeria)

SDGs Sustainable Development Goals

SGBV Sexual and Gender-Based Violence

$\mathrm{SRH} \quad$ Sexual and Reproductive Health

UNFPA United Nations Population Fund

UNICEF United Nations Children Fund

VAPP Violence Against Persons Prohibition

WHO World Health Organization 


\section{Acknowledgements}

This publication is based on research supported by UK Aid and the UK Government through the Department for International Development (DFID)-funded project "Evidence to End FGM/C: Research to Help Girls and Women Thrive," coordinated by the Population Council. The authors thank the following for their invaluable contribution to this review study. We wish to thank colleagues at Africa Coordinating Centre for the Abandonment of Female Genital Mutilation/Cutting (ACCAF); Prof. Jaldesa Guyo and Dr. Tammary Esho for their insights during the study. We greatly thank Drs Harriet Birungi, Michelle Hindin, Jacinta Muteshi, Timothy Abuya, and Caroline Kabiru of the Population Council, Kenya who provided critical insights and expertise that greatly improved the review, design, and implementation of the study. The contributions of Osasuyi Dirisu and Adetayo Adetunji are also acknowledged. We also thank Esther Lwanga and Chantalle Okondo for their support during the entire research project. 


\section{Executive Summary}

\section{Background}

Female genital mutilation/cutting $(\mathrm{FGM} / \mathrm{C})$ is a cultural practice that has health and human rights impacts on girls and women. The health sector has responsibility for prevention and response to provision of care services to women/girls with FGM/C-related complications. The mandate for the health sector response to $\mathrm{FGM} / \mathrm{C}$ is anchored in nationwide or sector-specific legal/policy instruments. Kenya and Nigeria, which are both characterised by high levels of medicalisation of the practice, have ratified global legal/policy instruments and adopted the WHO guidelines/tools for the prevention and management of $\mathrm{FGM} / \mathrm{C}$. To what extent the existing legal/policy documents in these two countries address prevention and response to management of $F G M / C$ has been unclear. In line with concurrent studies on medicalisation of the practice by the Evidence to End FGMC: Research to Help Girls and Women Thrive programme, we conducted a desk review to glean content on the prevention and management of $F G M / C$ in the laws, policies, plans of action, and guidelines of Kenya and Nigeria informed by each country's comparable legal governance structure and burden of FGM/C.

\section{Methods}

This content analysis was performed as part of a larger diagnostic assessment of the health sector's response to FGM/C prevention and management in Kenya and Nigeria. We sought to determine whether the FGM/C-related laws and policy documents in both countries sufficiently address prevention and response to management of $\mathrm{FGM} / \mathrm{C}$. We also identified the type of policy environment and opportunities that could be harnessed to trigger and stimulate abandonment and health sector responses towards FGM/C-related complications. To identify the relevant documents for revew, discussions were held with experts, researchers, key governmental and civil society policy actors, and stakeholders working on FGM/C in Kenya and Nigeria. The documents were then downloaded from the internet or obtained as hard copies. A content analysis was undertaken using researcher-developed criteria based on literature and knowledge of the researchers from Kenya and Nigeria. The analysis involved reading and populating a matrix with components for what a policy on FGM/C should contain. The components included definition, objectives, strategies relevant to $\mathrm{FGM} / \mathrm{C}$, reference to ratified and national instruments, prevention and management, implementation framework, and monitoring and evaluation among others.

\section{Results}

The Kenyan structure comprises two distinct but interdependent levels-one national and 47 subnational (county) governments. The constitution places responsibility of legal and policy formulation on the national government. In the absence of county legislation on a particular matter, the national law applies. The Nigerian governance system is a federal system of government comprising 36 states while the legal system entails English common law, Islamic law (in 12 northern states), and traditional law. The federal and state governments have a role in the enactment of laws with the federal government responsible for passing general laws, while states must enact, adopt, and implement the laws in their respective jurisdictions.

Both Kenya and Nigeria have comprehensive nationwide legal and policy frameworks that address prevention and response to $\mathrm{FGM} / \mathrm{C}$. The instruments include the constitution, legislation, and policies that provide a national roadmap across sectors, including health, on responses to $\mathrm{FGM} / \mathrm{C}$. Although the legislation/policies have articulated the specific health sector strategies for prevention and response to $\mathrm{FGM} / \mathrm{C}$, there is a weak link with laws that regulate professional conduct, namely the Medical Practitioners and Dentists Act in Kenya and Nigeria, and the Nurses Act and Clinical Officers Act in Kenya in regard to medicalisation. The instruments provide a general basis for which 
actions may be taken against their respective professionals for participating in malpractices such as medicalisation. However, the strategy appears to be ineffective, and more accountability as well as proactive initiatives by the regulatory bodies are required to respond to $\mathrm{FGM} / \mathrm{C}$ prevention.

There is a rich policy environment in the health sector for prevention and response to FGM/C management in Kenya and Nigeria. The policies include the following: the National Policy on the Eradication of Female Genital Mutilation of 2019, the National Adolescent Sexual and Reproductive Health (ASRH) Policy of 2015 and the National School Health Policy of 2018 for Kenya. In Nigeria, the practice of FGM/C is addressed through the National Policy and Plan of Action for the Elimination of Female Genital Mutilation in Nigeria 2013-2017, as well as the National Gender Policy of 2006, National Policy on the Health and Development of Adolescent and Young People of 2007, and the National Reproductive Health Policy of 2017. Although these policy documents have elapsed, the impact of their passing beyond their life-cycle is outside the scope of this review. The policies in both countries integrate important provisions and strategies to address $\mathrm{FGM} / \mathrm{C}$ that should guide and provide a conducive environment for robust health sector prevention and response to FGM/C management. However, the corresponding plans of action, guidelines, and tools of the policies are either outdated, obsolete, or lacking, potentially rendering the policies ineffective in harnessing the health sector potential to adequately prevent or respond to management of $F G M / C$. However, there are some notable insights on the gaps adduced from this review that affect FGM/C prevention and response. These include commitment from both governments; existence of national and subnational legal-governance structures; centrality of coordination and existence of an anti-FGM board; potential for localized/autonomous decisionmaking; integrated policy and plans-of-action approach; high turnover/development of legal/policy documents; reference to the existing legal/policy documents; availability of high-level policy leadership; and existing opportunities for integration of FGM/C.

\section{Conclusion}

Both Kenya and Nigeria have nationwide and health sector-specific laws/policies that integrate prevention and response to FGM/C. However, corresponding plans of action and guidelines are obsolete, or lacking. There is no awareness of and/or limited access to these instruments by those in a position to implement them on the ground, rendering the policy implementation process ineffective. These gaps are corroborated with the findings from the programme's field studies on medicalisation and the health system's response to FGM/C that showed a limited awareness of policies and a lack of integration, documentation, and guidelines/tools to support health providers in offering preventative and responsive care services to women with complications. These findings underscore the need to rally the health sector to keep fidelity with the policy provisions and strategies on addressing $F G M / C$, including working with nationwide $F G M / C$-response stakeholders. There is a need for integration of FGM/C into existing health programmes, and collaboration and partnership at all governance levels is critical.

\section{Implications for policy/programmes/research}

The study findings highlight several possible avenues for leveraging positive change:

- Conducting of professional dialogues in both countries to reinvigorate professional selfregulation, re-emphasis on the "Do No Harm" principle and development of disciplinary procedures.

- Leveraging on existing health programmes for integration of $F G M / C$ responses in Kenya.

- Ensuring stakeholder engagement/involvement to identify FGM/C-related health and rights impacts as a priority agenda for response. 
- Establishing of designated county anti-FGM/C board champions in line with the policy on eradication of $F G M / C$ in Kenya.

- Exploring the possibility of adopting simultaneous development of policy and plans of action.

- Reviewing and developing health sector-related FGM/C laws/policy and guidelines.

- Conducting additional health systems-focused research to better understand what is needed to implement FGM/C-related laws, policies, and guidelines. 


\section{Introduction}

\section{Background}

The practice of female genital mutilation/cutting (FGM/C) has drawn the attention of global policymakers because of its attendant health and human rights consequences on women and girls. In response, the policy makers have articulated FGM/C interventions in the global sustainable development goals' key target for the elimination of all harmful practises by 2030, while governments have reaffirmed their dedication by way of ICPD+25 commitments as well as ratified and adopted various international and regional legal/policy instruments. Kenya has ratified the international legal instruments and enacted several laws that address FGM/C: the Children's Act of 2001 (Laws of Kenya 2001); penal code (Laws of Kenya 2012); the Protection Against Domestic Violence Act of 2015 (Kenya Law 2015), and the Prohibition of Female Genital Mutilation Act of 2011 (National Council for Law Reporting 2011) that address prevention and response to FGM/C. Similarly, in Nigeria, the federal government enacted a legal framework that includes the nationwide Violence Against Persons (Prohibition) (VAPP) Act of 2015, which the states enact and adopt in order to respond and for accountability towards $F G M / C$, because of the governance structure in the country. Furthermore, about 13 states have so far enacted some laws banning FGM/C; such legislation is the Prohibition of Female Genital Mutilation of 2017 enacted in Imo State, the site of the wider health system study (28TooMany 2018b; Dirisu et al. 2020).

Recently, the impetus to address FGM/C in Kenya was boosted by a Presidential decree for accelerated elimination of the practice by 2022 with multi-stakeholders' roadmaps and strategies already rolled out. With the renewed impetus through high-level political-policy leadership and advocacy, the response to and elimination of FGM/C has been elevated to the level of a priority national agenda. With the various legal and policy instruments addressing FGM/C in Kenya and Nigeria, we expected that the health sector environment would be favourable in prevention and response to FGM/C. The key questions are: What policies and laws exist for addressing response to $\mathrm{FGM} / \mathrm{C}$, how have they been utilised in response to $\mathrm{FGM} / \mathrm{C}$, have they been effective in responding to $\mathrm{FGM} / \mathrm{C}$, and what needs to be done for legal/policy frameworks to accelerate and achieve abandonment of FGM/C in Kenya and Nigeria? This review highlights evidence generated from a desk appraisal of legal/policy documents addressing FGM/C prevention and management in Kenya and Nigeria as part of the wider "Evidence to End FGM/C" research programme.

\section{Objectives}

We conducted a desk review to glean the content of prevention and management of $F G M / C$ in Kenyan and Nigerian laws, policies, plans of action, and guidelines. The review was conducted as part of a larger diagnostic assessment of the health sector's response to FGM/C management and prevention in Kenya and Nigeria. Specifically, the desk appraisal sought to address the following objectives:

1. To identify laws, policies, and guidelines that address response to management and prevention of FGM/C;

2. To determine specific components of FGM/C-related health management and prevention interventions addressed by the various legal/policy documents;

3. To identify gaps and opportunities in the policy environment for addressing FGM/C in the two countries. 


\section{Methods}

The choice of Kenya and Nigeria was informed by several factors. Each country is characterised by high levels of medicalisation of the practice and an overall high burden of FGM/C in terms of absolute numbers. They are priority countries for the UNFPA-UNICEF Joint Programme on Elimination of FGM/C and have comparable legal governance structures. Evidence to End FGMC: Research to Help Girls and Women Thrive has conducted field studies on medicalisation and on the health system's response to FGM/C in each country. To better understand the Kenyan and Nigerian health systems' response to the management and prevention of FGM/C, the review examined FGM/C-related policies using Walt and Gilson's policy triangle model (Walt and Gilson 1994) as a framework for understanding the FGM/C policy implementation processes in both countries. The framework emphasises that effective policy analysis entails examining the content of policies, the role of actors and how they interact and influence policy, the processes through which such influence is played out (e.g., in formulating and implementing policy) and the context in which these different actors and processes interact. The framework was applied to analyze and understand existing FGM/C-related policies in terms of the content, different policy stakeholders, and process (of formulating policy), alongside contextual stakeholders (social, political, economic) to determine the health system's implementation of FGM/C prevention and management services.

The relevant Kenyan and Nigerian documents for review were identified through discussions with experts, researchers, key governmental and civil society policy actors, and stakeholders in the FGM/C response. The documents were downloaded from the internet or obtained as hard copies from relevant agencies. Additionally, the laws and policies were identified through careful review of these documents cited by key stakeholders. The laws and policies that were documented and reviewed for both countries are listed in Table 1 below. The researchers reviewed each document (Dr. Kimani for Kenya and Dr. Obianwu for Nigeria) and made notes using review questions as a guide. The analysis was conducted to determine whether the documents sufficiently address prevention and management of FGM/C-related complications within the health system, outline concrete steps for health system involvement in FGM/C prevention and management, and the extent to which they facilitate or inhibit health system FGM/C response efforts at national/federal or state/county levels. The content analysis also sought to answer the following questions:

- What is the health system's vision regarding FGM/C prevention and management?

- Do the policies clearly state the goals or objectives and strategies relevant to FGM/C response?

- Do the policies make reference to global/regional or national instruments that address $\mathrm{FGM} / \mathrm{C}$ ?

- What are the core components with regard to FGM/C prevention and management?

- Who are the health system actors responsible for implementing $\mathrm{FGM} / \mathrm{C}$ prevention/management and what are their duties?

- Does the policy articulate the mechanism for monitoring implementation?

- Does the policy identify indicators for assessing programme success? 
Table 1. FGM/C-related laws and policy documents in Kenya and Nigeria

\begin{tabular}{|c|c|}
\hline Kenya & Nigeria \\
\hline $\begin{array}{ll}\text { - } & \text { Prohibition of FGM Act, } 2011 \\
\text { - } & \text { Children's Act of } 2001 \\
\text { - } & \text { Penal Code Cap } 63 \\
\text { - } & \text { Protection Against Domestic Violence Act } 2015 \\
\text { - } & \text { Medical Practitioners and Dentists Act (Revised } \\
\text { - } & \text { Nurses Act (Revised 2011) } \\
\text { - } & \text { National Policy for the Eradication of Female } \\
\text { - } & \text { National Adolescent Sexual and Reproductive } \\
\text { - } & \text { Neation Policy } 2015 \\
\text { - } & \text { National Pchool Health Policy } 2019 \\
\text { - } \quad \text { FGM in Kenya } 1999-2019 \\
\text { Reference Manual for Health Care Providers on } \\
\text { Management of Complications from FGM/C } \\
\text { (2007) }\end{array}$ & $\begin{array}{ll}\text { - } & \text { Medical and Dental Practitioners (Disciplinary } \\
\text { - } & \text { Tribunal) Rules, } 2004 \text { (the Medical Act) } \\
\text { - } & \text { HIV and AIDS (Anti-Discrimination) Act, } 2014 \\
\text { - } & \text { Violence Against Persons Prohibition Act } 2015 \\
\text { - } & \text { Imo State Female Genital Mutilation Law } 2017 \\
\text { - } & \text { National Gender Policy } 2006 \\
\text { - } & \text { National Policy on the Health and Development } \\
\text { of Adolescents and Young People in Nigeria } \\
\text { - } \\
\text { National Gender Policy Strategic Framework } \\
\text { - } \quad \text { Implementation Plan) 2008-2013 } \\
\text { Eliminal Policy and Plan of Action for the } \\
\text { Nigeria 2013-2017 }\end{array}$ \\
\hline
\end{tabular}

\section{Results}

\section{What legal and governance environments exist in Kenya and Nigeria?}

In Kenya, the legal-governance structure comprises two distinct but interdependent government levels: one national and 47 subnational (county) governments. Legally, Kenya follows the English common law system. The constitution places responsibility for legal and policy formulation on the national government (28TooMany 2018a; Government of Kenya 2010). Therefore, the nationally enacted laws and policies of non-devolved functions such as security and justice supersede any of those passed at the sub-national level. Functions like health are devolved, but the mandate for policy formulation is placed on the national level. In the absence of subnational legislation on a particular matter, the national law applies. On the other hand, Nigeria has a complex legalgovernance system made of a federal system of government comprising 36 states, and a legal system that entails English common law, Islamic law (in 12 northern states), and traditional law. Legally, federal and state governments both have a role in the enactment of laws prohibiting FGM/C. Thus, although the federal government is responsible for passing general laws, the state governments must enact, adopt, and implement the laws in their respective states (28TooMany 2018b).

\section{What laws address FGM/C prevention and response in Kenya and Nigeria?}

Kenya and Nigeria are signatories to a number of international human rights instruments that condemn, outlaw, and criminalise FGM/C. Health sectors in the two countries are guided by a number of nationwide FGM/C-related legal instruments that address the abandonment of the practice. First, the Kenyan Constitution (Government of Kenya 2010) (28TooMany 2018a) guarantees fundamental rights by way of clauses that affirm commitment for protection and promotion of human rights and fundamental freedoms. Specifically, Articles 29(c) and (f) prohibit subjecting any person to any form of violence, and outlaw treatment or punishment in a cruel, inhuman, or degrading manner. Article 44 (3) prevents anyone from compelling any person to perform, observe, or undergo any cultural practise or rite. Article 53(d) provides that children not be subjected to abuse, neglect, harmful cultural practises, and all forms of violence, inhuman treatment, and punishment. Similarly, the Constitution of the Federal Republic of Nigeria of 1999 
(Nigeria 1999) in Article 15 (2) prohibits discrimination; Article 17 (2) guarantees equality of rights, and provides for respect and dignity of every person and Article 34 (1) prohibits subjecting a person to torture, or to inhuman or degrading treatment (28TooMany 2018b). It appears that Kenya's constitution has more clearly stated provisions addressing FGM/C, while the Nigeria constitution more broadly encapsulates discrimination and equality rather than mention of FGM/C.

Second, in furtherance of the provisions of the constitution and the ratified international instruments, the two governments have enacted legislation that specifically addresses FGM/C. In Kenya, such legislation includes the Prohibition of FGM Act of 2011 (National Council for Law Reporting 2011) as the most comprehensive laws addressing FGM/C. The law defines offences and punishments for engaging in all forms of $\mathrm{FGM} / \mathrm{C}$ including medicalisation (Table $\mathbf{A} 1$ in the Appendix). It also has provisions for creation of awareness on FGM/C-related negative impacts. The relevant health sector provisions in the Act include: criminalises performance of $F G M / C$ by a medical practitioner, nurse/midwife or their corresponding trainees; and criminalises performance of FGM/C by health providers on any ground including consenting by the client. Furthermore, it criminalises the following acts: use of premises (clinics/health facilities) to perform FGM/C; possession of tools or equipment for FGM/C; aiding, abetting, or procuring $\mathrm{FGM} / \mathrm{C}$; procuring a person to perform $\mathrm{FGM} / \mathrm{C}$ in another country (cross-border $\mathrm{FGM} / \mathrm{C}$ ); and failure to report commission of $F G M / C$ to law enforcement officers, when FGM/C is in progress, has already occurred or is planned. The Act prescribes specific penalties/punishments for FGM/C-related offences including imprisonment for a minimum of three years, and/or a fine of at least 200,000 shillings (US\$1,941). In the event that FGM/C results in death, the Act prescribes the maximum sentence as life imprisonment. The use of derogatory or shaming language in relation to FGM/C is subject to punishment for a minimum of six months' imprisonment or a fine of at least 50,000 shillings (US\$485), or both. Furthermore, the Act provides for the establishment of the anti-Female Genital Mutilation Board with a mandate to offer leadership and coordination in FGM/C-related policy, programming, and investment interventions. In Nigeria, FGM/C is criminalized by the federal law-the Violence Against Persons (Prohibition) (VAPP) Act of 2015 (28TooMany 2018b; Federal Government of Nigeria 2015). However, since the Nigerian governance system requires both the federal and state governments to enact laws, the VAPP Act does not apply nationwide. Therefore, the VAPP Act is only applicable in the Federal Capital Territory and in states that have enacted and adopted its provisions. The VAPP Act has provisions that criminalise FGM/C in women or girls. The Act defines offences and punishments for performance of and related crimes around FGM/C. The relevant provisions in the Act include: performance of $\mathrm{FGM} / \mathrm{C}$, or engaging another person to carry out $\mathrm{FGM} / \mathrm{C}$ is punishable by imprisonment not exceeding four years or a fine not exceeding N200,000 or both; attempting to perform FGM/C or to engage another person to carry out FGM/C is punishable by imprisonment not exceeding two years or a fine not exceeding N100,000 or both; inciting, aiding, abetting, or counselling another person to perform $F G M / C$ is punishable by imprisonment not exceeding two years or a fine not exceeding N100,000 or both.

Third, prior to the passage of the VAPP Act 2015, some Nigerian states had enacted legal provisions that prohibit FGM/C (Table A2 in the Appendix). Indeed, 14 out of the 36 Nigerian states have so far passed laws criminalising FGM/C (28TooMany 2018b). An example of legislation passed by individual state is the FGM Prohibition Law of 2017, in Imo State with the aim of prohibiting $\mathrm{FGM} / \mathrm{C}$ and other related matters. The law has provisions that prohibit/criminalise FGM/C regardless of custom or tradition. The Act defines offences and punishments for performing of FGM/C. The relevant provisions in the Act include: separating or surgically altering the normal healthy functioning genital tissue/organ of a female shall attract 14 years' imprisonment or a fine of N250,000; for aiding and abetting FGM/C one is liable for seven years+ imprisonment or a fine of N150,000; an adult willingly submitting for FGM/C is liable for 14 years+ imprisonment or a fine of N250,000; assaulting or causing suffering or discrimination for not having undergone FGM/C is 
punishable by three years' imprisonment and/or a fine of N100,000; facilitating cross-border $\mathrm{FGM} / \mathrm{C}$ is punishable by 14 years' imprisonment or a fine of $\mathrm{N} 250,000$.

Fourth, in Kenya, there is additional legislation that supplements the aforementioned Kenyan instruments in response to FGM/C. These include the Children's Act of 2001 (Laws of Kenya 2001) which has provisions for the protection of children (below 18 years) from FGM/C by way of clauses explicitly stating "no person shall subject a child to female circumcision, or other cultural rites, customs or traditional practises that are likely to negatively affect the child's life, health, social welfare, dignity or physical or psychological development." The Protection Against Domestic Violence Act of 2015 (Kenya Law 2015) defines and classifies FGM/C as a form of violence. The Act provides for protective measures for survivors and victims of domestic violence including FGM/C. The Penal Code, Cap 63 (Laws of Kenya 2012), has provisions for offences under which the circumcisers can be charged. Thus, the Penal Code and the aforementioned Acts are read and interpreted together to protect and seek justice for the survivors of FGM/C. Similarly, additional laws addressing FGM/C in Nigeria include: Islamic (Sharia) law, enacted by some northern Nigerian states with provisions for the protection of children from different forms of psychological and physical violence (28TooMany 2018b). The HIV and AIDS (Anti-Discrimination) Act of 2014 in Section 3 (3), 2014 prohibits any "culture, practise or tradition" that can increase people's HIV risk. Furthermore, the National Health Act of 2014 in Section 48 (1) has provisions governing the removal of tissue, blood, or blood products of a living person. It states that such an act is only legal if it is done with the informed consent of that person, for medical investigations and treatment in emergency cases (where consent can be waived) and in accordance with guidelines given by an appropriate authority. The Act also states in Section 48 (2) that a person shall not remove tissue which is not replaceable by natural processes from a person younger than eighteen years.

Fifth, in the Kenyan health sector, specific legislations-namely the Medical Practitioners and Dentists Act (Government of Kenya 2012), Nurses Act (Government of Kenya 2011) and Clinical Officers Act (Government of Kenya 2017)—do not explicitly criminalise FGM/C. However, they state that disciplinary proceedings may be brought against a medical practitioner, a nurse or clinical officer who commits an offence under the penal code or engages in "any infamous or disgraceful conduct in a professional respect," which will result in removal from the respective medical, nurses, or clinical officers registers or cancellation of their licenses. Likewise, in Nigeria, the Medical and Dental Practitioners (Disciplinary Tribunal) Rules 2004 (the Medical Act), does not explicitly refer to $\mathrm{FGM} / \mathrm{C}$, but states that, where a registered medical practitioner is found guilty of professional misconduct by the Medical Disciplinary Tribunal or is convicted by any court of law or tribunal for an offence considered incompatible with the status of a medical practitioner, he or she may be subject to penalties (Section 16 under "Penalties for Professional Misconduct"). In both countries, the laws regulating the conduct of the medical professions are not explicit on responding to those who participate in medicalisation. The interpretation is that the laws need to be read together with national laws such as the Prohibition of FGM Act and the VAPP Act.

Sixth, the Kenyan legislative instruments have provisions that respond to management of $\mathrm{FGM} / \mathrm{C}$. Specifically, the Prohibition of FGM Act has provisions for protection of women and girls from FGM/C including safe housing; provision of support services to victims of FGM/C to include medical services and psychosocial support; as well as public education and sensitisation on the dangers and adverse effects of $\mathrm{FGM} / \mathrm{C}$, providing the required information to seek medical services and support. The Children's Act has the following provisions relevant for FGM/C management: recording and preservation of evidence on $\mathrm{FGM} / \mathrm{C}$ by medical officers and health facilities; waiver of any expenses incurred in connection with FGM/C-related medical treatment or hospitalisation of a child; and provision for safe housing or custody interventions for care, and protection of a child in danger of imminent injury or harm. Similarly, the Protection Against Domestic Violence Act of 2015 provides for invocation of protection orders for the victim in safe custody, as well as covering 
potential victims against engagement, or threats to engage, in cultural or customary rites or practises that abuse the victim. It also has provision for counselling the victim to promote a protective environment for all. Similarly, in Nigeria, the VAPP Act of 2015 has provisions that address $\mathrm{FGM} / \mathrm{C}$ management, including the right to information on health services available; entitlement to comprehensive health services from both governmental and nongovernmental agencies; and entitlement to easy access to health services through provision of transport to the nearest health facility. Additionally, the federal Ministry of Health is required to document and disseminate information about accredited health service providers as well as develop guidelines for the operation of the service providers. Similarly, the Imo State FGM/C Prohibition Law has the following provisions: information-sharing with community members on the health risks and complications related to $\mathrm{FGM} / \mathrm{C}$; charges the State Ministry of Health with documenting data on girls/women who have undergone $\mathrm{FGM} / \mathrm{C}$; and ensuring that $\mathrm{FGM} / \mathrm{C}$ is integrated into the curricula of health professional training institutions in the state.

\section{What are the policies that address FGM/C prevention and response in Kenya and Nigeria?}

The Kenyan and Nigerian governments, through various ministries including health, have developed policies that set out health sector-related strategies for addressing FGM/C. Tables A3 and A4 in Appendix 2 provide summaries of health sector relevant components in these policies. In Kenya, FGM/C is addressed in the recent National Policy for the Eradication of Female Genital Mutilation of 2019 (Ministry of Gender Affairs 2019) as well as health sector-specific National Adolescent Sexual and Reproductive Health Policy of 2015 (Ministry of Health 2015) and the National School Health Policy of 2018 (Ministry of Education 2018). These policies actualide the ratified international instruments, the constitution, and the country's legislation that address FGM/C as a harmful practise and a topical issue as defined by the World Health Organization. These policies have considered the devolved governance structure and sector-specific changes in setting out strategies for addressing FGM/C. In Nigeria, FGM/C is addressed through a nationwide policy titled the National_Policy and Plan of Action for the Elimination of FGM of 2013-2017 (Federal Ministry of Health 2013) as well as other sector-specific policies including: the National Gender Policy of 2006, the National Policy on the Health and Development of Adolescents and Young People of 2007, and the National Reproductive Health Policy of 2017 (Federal Ministry of Health 2017). This review's main focus is on the National Policy and Plan of Action for the Elimination of FGM of 2013-2017.

Understandably, the aforementioned Kenyan policies highlight FGM/C as a human rights and health issue that needs to be addressed in order to mitigate its impacts. The three policies refer to the ratified global/regional instruments as well as the national legislation that address FGM/C and on the guiding principle of respect for human rights. The Adolescent Sexual and Reproductive Health (ASRH) and National Policy for the Eradication of FGM policies cite Kenyan legal instruments, namely: the constitution, the Children's Act, the Prohibition of FGM Act, Penal Code Cap 63, and the Protection Against Domestic Violence Act that address FGM/C. They also refer to older policies that addressed FGM/C, namely the National School Health Policy of 2009 and National Policy on Abandonment of FGM 2010 that provided the platform for the enactment of the Prohibition of FGM Act of 2011 and the establishment of the Anti-FGM Board. The National School Health Policy provides guidelines for the protection and safeguarding of children by responding to FGM/C prevention and management, citing the Children's Act of 2001. In Nigeria only the National Policy and Plan of Action for the Elimination of FGM defines the practice as per the WHO guidelines. The policy is aligned with the global and national legal/policy contexts that address FGM/C on the premise of respect for human rights as a guiding principle and as a medico-social issue. The policy is within the framework of the National Gender, Health, and Strategic 
Development Plan in Nigeria. It outlines the response from government and civil society organisations to include community-level education, capacity-building for stakeholders on the negative impact of $\mathrm{FGM} / \mathrm{C}$, advocacy for legislation and treatment of $\mathrm{FGM} / \mathrm{C}$ complications, intersectoral collaboration and integration of anti-FGM/C programmes in relevant sectors, and antiFGM/C legislation at state levels.

The strategic objectives to address FGM/C in the specific aforementioned policies are highlighted here. In the Kenya National Policy on Eradication of FGM the following are highlighted: to accelerate the eradication of $\mathrm{FGM} / \mathrm{C}$ in Kenya; strengthen multi-sectoral interventions, coordination, networking, partnership, and community participation in accelerating the eradication of FGM/C; and address emerging trends and practises largely aimed at avoiding enforcement of the law; address gender inequality by promoting the empowerment of girls and women; strengthen research, data collection, and information and knowledge management on FGM/C. The ASRH policy addresses FGM/C by way of the following: promote adolescent sexual and reproductive health and rights; reduce harmful traditional practises and incidence of sexual and gender-based violence to improve the response. Similarly, the National School Health Policy responds to FGM/C through: promoting gender-related issues in schools; enhancing child rights and protection in schools; informing learners, parents, and community on the rights and responsibilities of the child; safeguarding children from child rights abuse; safeguarding learners from all forms of gender based violence and harmful cultural practises as well as helping them transcend gender dynamics that may affect their education, health, and wel-lbeing. In Nigeria, the National Policy and Plan of Action for the Elimination of FGM of 2013-2017 highlights the following strategic objectives in addressing $\mathrm{FGM} / \mathrm{C}$ : to reduce the prevalence of female genital mutilation; promote community behavioural change initiatives towards elimination of FGM/C; establish a legal framework for the elimination of FGM/C at national and state levels; and to strengthen the system for research, monitoring, and evaluation towards the elimination of $\mathrm{FGM} / \mathrm{C}$.

The Kenyan policy documents also highlight FGM/C-related prevention and management priority action areas. The national policy on eradication of $\mathrm{FGM} / \mathrm{C}$ addresses the following policy priority actions: promote public education and community dialogues on $\mathrm{FGM} / \mathrm{C}$; support enforcement of the existing laws related to $\mathrm{FGM} / \mathrm{C}$; engage women, girls, men, and boys in the prevention of $\mathrm{FGM} / \mathrm{C}$; include FGM/C content in the curricula of learning institutions; strengthen capacity of institutions and communities to prevent and respond to $\mathrm{FGM} / \mathrm{C}$; develop initiatives to address cross-border FGM/C; prevent FGM/C in humanitarian and emergency situations; promote the empowerment of women and girls; and develop and implement a monitoring and evaluation framework. The ASRH of Kenya targets the following policy priority actions: capacity-strengthening of institutions, communities, families, and individuals to prevent and respond to $\mathrm{FGM} / \mathrm{C}$; male involvement in prevention of FGM/C; monitoring and evaluation (M\&E) of FGM/C interventions; supporting the management of health consequences of FGM'C; supporting the implementation of policies/programmes, enforcement of legislation to reduce the practice; supporting the sensitisation of communities on existing legislation and policies that protect and prevent $\mathrm{FGM} / \mathrm{C}$; supporting programmes and research on $\mathrm{FGM} / \mathrm{C}$ as well as promoting appropriate evidence-based interventions; supporting sensitisation of reintegration into school of adolescents in $\mathrm{FGM} / \mathrm{C}$ situations; strengthening provision of medical, legal, and psychosocial support for victims/survivors of FGM/C; and enhancing capacity of law enforcers and health service providers on prevention and mitigation of FGM/C. Similarly, the national school health policy addresses the following policy priority areas: gender issues including $\mathrm{FGM} / \mathrm{C}$ and how they affect health; schools' and communities' sensitisation to and support for abandoning FGM/C; enlightenment of youth on FGM/C through sensitisation campaigns; provision of information to students on the existence of FGM/C; awareness-creation among students on consequences of $F G M / C$; education of the pupils, 
teachers, parents, and communities on FGM/C and control measures; and counselling and rehabilitation of students exposed to FGM/C.

In Nigeria, the National Policy and Plan of Action for the Elimination of FGM of 2013-2017 highlights the following priority actions: capacity-building for prevention and management of FGM/C complications; integration of FGM/C into SRH/HIV services; advocacy for training institutions for healthcare providers to integrate an FGM/C module into their training curricula; sensitisation of regulatory bodies and professional associations for healthcare providers on medicalisation of FGM/C; M\&E support to regulatory authorities to monitor FGM/C practises in the health sector; behaviour change communications material development; organising workshop to define, identify \& develop indicators/data collection tools; capacity building through trainings for M\&E personnel from all FGM/C stakeholders to address capacity gaps for utilising data-capturing tools; and research, documentation, and information sharing.

The policies in both countries have detailed implementation frameworks with considerations for the institutions, actors and stakeholders who should be involved across all levels. The policies propose implementation plans encompassing a multi-sectoral approach, involvement of national and subnational governments, state and nonstate actors (multi-sectoral technical working groups) with provisions for stand-alone plans of action. In Nigeria, the policy provides for actors and stakeholders to be drawn from federal, state, and local government area and communities as administrative units. However, the Nigerian policy has the national action plan integrated into the policy. In both countries, the leadership for implementation of various policies is vested in the ministry where the policy resides, for example, the Ministry of Health is to lead ASHR policy. There is no coordination body for anti-FGM/C policies and programmes in Nigeria whereas Kenya has one. The proposed implementation framework for Kenya is to be guided by a plan of action, other national policies, and priority actions through a multi-sectoral approach to collaborations and partnerships.

With regard to the implementation of FGM/C policies in Kenya, there are structures identified and their roles clearly highlighted to include: the national, subnational, hospital level, subcounty, and community levels depending on the policy. The policies have provisions on mobilising resources for $\mathrm{FGM} / \mathrm{C}$ prevention and responses to actualise the policies - a responsibility of the lead ministry and partners. In Nigeria, the policies identify health system actors responsible for implementing FGM/C prevention/management activities including the Ministry of Health, co-leading with the Ministry of Women Affairs for coordinating the FGM/C response at both federal and state levels, primary healthcare development agencies, hospital management boards, health professional regulatory bodies, and health professional associations.

Finally, in Kenya the reviewed policies had elaborate M\&E strategies for their implementation that involves timely reporting, updates, and consistent monitoring to inform programming on any emerging FGM/C trends. Furthermore, the National Policy and Plan of Action for the Elimination of FGM/C in Nigeria 2013-2017, describes a plan for periodically monitoring and evaluating activities implemented at community, local government area, state, and national levels and provides indicators for assessing programme success.

\section{What plans of action address FGM/C prevention and response in Kenya and Nigeria?}

The Kenyan and Nigerian governments have developed sector-specific national plans of action and strategic frameworks that set out implementation strategies to address FGM/C. In Kenya these include the National Plan of Action for Children in Kenya 2015-2022 (2015), the National Plan of Action for the Elimination of FGM in Kenya (1999-2019), and the National School Health Strategy Implementation Plan (2011-2015) (Ministry of Public Health and Sanitation \& Education 2015) 
which were addressed in this review. In Nigeria the National Strategic Framework on the Health and Development of Adolescents and Young People in Nigeria 2007-2011, National Gender Policy Strategic Framework (Implementation Plan) 2008-2013, and the Plan of Action component of the national policy were examined. The Plan of Action for the Elimination of Female Genital Mutilation in Nigeria (2013-2017) had relevant FGM/C-related prevention and management components. Tables A5 and A6 in Appendix 2 provide a summary of the components of these plans of action and strategic frameworks.

It is noteworthy to observe that in Kenya, the health sector-relevant FGM/C-specific policies are more recent and current. However, their corresponding national plans of action were either outdated or unavailable. It would be important to understand the impact of this phenomenon in the policy implementation. Our interpretation is that this could be a weak link in the implementation of the health-related policies that address FGM/C in Kenya. It is no wonder, therefore, that health sectors have been less visible in addressing prevention and response to FGM/C in Kenya. It is important to note the Nigeria National Policy and Plan of Action for the Elimination of Female Genital Mutilation in Nigeria (2013-2017) is a combined policy and plan of action document. It helped to have the two documents simultaneously for completion of policy formulation and to avoid fatigue associated with the process. To what extent this integrated, simultaneous approach of policy-plan of action development facilitates policy formulation is a subject beyond this appraisal.

\section{What guidelines address FGM/C prevention and management in Kenya and Nigeria?}

The Kenyan Ministries of Health and Education have developed national school health guidelines that describe interventions that address school health challenges including response to prevention and management of FGM/C at basic education levels. Table A7a provides a summary of the components relevant to prevention and management of FGM/C. Additionally, the Kenyan Ministry of Health in 2007 developed a reference manual (Ministry of Health 2007) for the management of complications, in pregnancy, childbirth and the postpartum period in the Presence of $F G M / C$. The guideline highlights the knowledge, skills and competencies for healthcare providers to competently address prevention and management of FGM/C. Table A7b provides a summary of the components on FGM/C prevention and management in the guideline. Nigeria lacked specific guidelines for the prevention and management of FGM/C. Instead there exist Federal Ministry of Health $(\mathrm{FMOH})$ "standards and guidelines for the medical management of victims of violence in Nigeria" developed by the FMOH (Table A8). 


\section{Discussion}

The Kenyan structure comprises two distinct but interdependent levels-one national and 47 subnational (county) governments. The constitution places responsibility for legal and policy formulation on the national government. In the absence of county legislation on a particular matter, the national law applies. The Nigerian governance system is a federal system of government comprising 36 states while the legal system entails English common law, Islamic law (in 12 northern states), and traditional law. The federal and state governments have a role in the enactment of laws with federal government responsible for passing general laws, while states must enact, adopt, and implement the laws in their respective jurisdictions.

The analyses showed that Kenya and Nigeria have comprehensive nationwide legal and policy frameworks that address prevention and response to $F G M / C$. The instruments include the constitution, legislation, and policies that provide a national roadmap across sectors including health on responses to $\mathrm{FGM} / \mathrm{C}$. The laws and policies reveal the governments' commitment to elimination of $\mathrm{FGM} / \mathrm{C}$ and other harmful practises as well as addressing human rights and violence against women/girls. Although, the legislation/policies have articulated the specific health sector strategies for prevention and response to $\mathrm{FGM} / \mathrm{C}$, there is a weak link with laws that regulate professional conduct, namely the Medical Practitioners and Dentists Act in Kenya and Nigeria, and the Nurses Act and Clinical Officers Act in Kenya with regard to the medicalistion of FGM/C. The instruments provide a general basis for which actions may be taken against their respective professionals for participating in malpractice such as medicalisation. However, the strategy should include proactive initiatives that involve regulatory bodies and professional associations to implement the Prohibition of FGM Act of 2011 (National Council for Law Reporting 2011). Besides defining the offences such as medicalisation and prescribing punishments/fines, the Act also provides for the sensitization and creation of awareness of FGM/C-related health complicationsa core mandate that fits the functions of the health sector. The implementation of the Act should also include conducting professional dialogues that involve raising awareness of the Prohibition of FGM Act and its content including medicalisation. The interventions should be implemented through involvement of professional regulatory bodies, associations, and societies as a mechanism of reinvigorating professional self-regulation, re-emphasis on the "Do No Harm" principle, and development of disciplinary procedures

There is rich policy environment in the health sector for prevention and response to FGM/C management in Kenya and Nigeria. The policies include the National Policy for the Eradication of Female Genital Mutilation of 2019, the National Adolescent Sexual and Reproductive Health Policy of 2015 and the National School Health Policy of 2018 for Kenya. In Nigeria, the practice of FGM/C is addressed through the National Policy and Plan of Action for the Elimination of FGM of 20132017, as well as the National Gender Policy of 2006, National Policy on the Health and Development of Adolescents and Young People of 2007, and the National Reproductive Health Policy of 2017. The policies in both countries integrate important provisions and strategies addressing $\mathrm{FGM} / \mathrm{C}$ that should guide and provide a conducive environment for robust health sector prevention and response to $\mathrm{FGM} / \mathrm{C}$ management. Although some of the policy documents have elapsed, the impact of their passing beyond their life cycle is outside the scope of this review. However, health interventions in service delivery points lack FGM/C prevention services while responses to practice-related complications are unstructured (Kimani \& Okondo, 2020)

The reasons FGM/C-related laws/policies may not have been effective in harnessing the health sector potential to adequately respond to $\mathrm{FGM} / \mathrm{C}$ in the two countries are corroborated by findings from field studies in Kenya (West Pokot County) and Nigeria (Imo State). The findings showed limited awareness and dissemination of policies, a lack of guidelines and tools to support FGM/C prevention and response, and a lack of FGM/C data capture and documentation (Dirisu et al. 2020; 
Kimani and Okondo 2020). This review points to a number of gaps: first, Kenya has FGM/Crelevant health sector policies that are current but their corresponding plans of action are either outdated or lacking, while Nigeria has an integrated policy and plan of action that is also expired. Second, Kenya has current school health guidelines and a 2007 Ministry of Health FGM/C-related guideline established before the Prohibition of FGM Act; however, Nigeria lacks FGM/C-related guidelines and tools for prevention and management of FGM/C. Third, there is substantial turnover of health sector FGM/C-related policies in both countries that should have identified gaps in the implementation process, but there is no evidence to the effect. The gaps are observed despite the policies having an elaborate monitoring and evaluation framework that should guide accountability and their implementation. These findings raise a red flag for the health sector for not faithfully implementing their own policies, thus denying women and girls their rights and right to quality health services.

\section{What can we learn from the FGM/C legal/policy analyses in Kenya and Nigeria?}

Availability of well-articulated legal and policy documents: The analyses showed that Kenya and Nigeria have comprehensive nationwide and health sector-specific legal/policy frameworks that address prevention and response to $\mathrm{FGM} / \mathrm{C}$. The instruments include the constitution, legislation, and policies that provide a national roadmap across sectors on response to FGM/C. Although the laws/policies reveal the governments' commitment to addressing FGM/C, human rights, and violence against women, the question that remains is what would it take to transform the instruments into meaningful actions targeting girls/women in response to FGM/C?

Existence of similarities and differences in the legal-governance environment: Kenya and Nigeria have some similarities as well as differences in their legal and governance structures. The Kenyan governance structure has two distinct but interdependent tiers of government at national and subnational levels. Legal and policy formulation is the mandate of the national government and the laws enacted at the national level supersede any legislation made at the county level. This could facilitate formulation and central control of the policy process but also risks a longer process, and problems with dissemination and implementation. The Nigerian legal system has federal and state levels of governance with both structures having a role in enactment of laws and development of policies. Although the federal government is responsible for passing general laws, the state governments must adopt and implement them within their respective states (28TooMany 2018b). This could facilitate quick development of policies and promote faster implementation becase of few layers of governance structure at the state level.

Centrality of control and standardised responses to FGM/C: The Kenyan governance structure could allow for faster implementation because there is no political bureaucracy associated with two independent governance structures. It can also offer central control and the potential for influence from strong national policy leadership and a standardized approach to implementation and accountability. The disadvantage would be when the problem is localised; for example, FGM/C is not prevalent in all counties. Although FGM/C is practised by most ethnic communities in Kenya, in most of the counties it is uncommon and thus not taken as a priority issue affecting legal/policy implementation.

Potential for localised and autonomous decisions: The Nigerian governance structure could be advantageous in situations where FGM/C is identified as a priority issue by states. This could trigger a faster process of legal/policy formulation because of fewer national and state-level bureaucracies. However, the disadvantage could be that most federal government are obliged to ratify and enact international instruments, a requirement not applicable to states. This could impact implementation; additionally, the autonomous nature of the states can lead to no standard approaches to addressing FGM/C. 
Existence of a central anti-FGM/C coordination body: Kenya has established an anti-FGM/C board to spearhead FGM/C-related policy and programme coordination and leadership. This has helped the country develop approaches for addressing FGM/C, including creating a conducive legal/policy environment. However, the board is not devolved, leading to the perception that these policies have limited impact at the county level. However, the recently approved National Policy on Eradication of FGM provides for a designated anti-FGM board representative in the counties. There is no such anti-FGM/C body in Nigeria. This could affect prevention and response to FGM/C including development of policy instruments.

Availability of integrated policy together with plans of action: In Nigeria, there is an integrated policy with a plan of action. This is an innovative approach to policy formulation as it can prevent fatigue and prolonged time lapse associated with policy formulation. Additionally, it can promote implementation because the strategy is not forgotten as in situations where the two are developed separately. Such gaps were seen in the Kenyan health sector-related policies and earlier policies developed in Nigeria where the policies were well articulated but national plans of action were missing. Indeed, despite the well-articulated health-related policies, the national plans of action were unavailable, leading to questions about fidelity in their implementation.

Turnover/development of health-related legal/policies: A notable issue was the high rate of change/development of policies in both countries. The development or review of policies should evaluate any expiring version to see how much it achieved its objective. However, this analysis showed this is not to be the case, with some policies retiring before their corresponding plans of actions had been developed. This questions the principle and intent of the policies, as well as the willingness to implement them.

Lack of guidelines and tools to address FGM/C: There was lack of guidelines and tools on the prevention and response to management of FGM/C in Nigeria. The evidence is consistent with field study findings that showed that healthcare workers did not have guidelines or tool to facilitate their care services to those with $\mathrm{FGM} / \mathrm{C}$. In the absence of guidelines and tools aligned to the WHO tool, provision of high-quality care services to girls and women living with $\mathrm{FGM} / \mathrm{C}$ complications would be compromised.

Reference to the existing legal/policy documents: Reference to the existing legal/policy documents is a common feature in most Kenyan policies. This is an indication of wider stakeholder consultation, reference to existing literature, and a guarantee for continuity. The the review and development of new policies should thus answer the question as to what extent implementation of the expiring legal/policy documents was achieved.

Availability of high-level policy leadership for FGM/C in Kenya: The renewed policy leadership in Kenya provides an opportunity to reengineer a response on $\mathrm{FGM} / \mathrm{C}$. In the 2019 conference on $I C P D+25$, various governments made commitments to scale up response to $F G M / C$, with the President of Kenya issuing a directive for accelerated elimination of FGM/C by 2022. The directive has triggered development of multi-stakeholders and multi-sectoral roadmaps and strategies for addressing FGM/C. Such interventions provide a perfect policy and implementation environment and the requisite impetus for $\mathrm{FGM} / \mathrm{C}$ strategies. This will have a significant impact on the fight against $F G M / C$ in Kenya whose trajectory had shown very positive indicators.

Existing opportunities for integration of FGM/C in Kenya: Kenya's health sector has ongoing programmes including maternal and child health, nutrition, and school health. The programmes are currently integrating and refocusing to respond to the goals of universal health care (UHC) part of the BIG FOUR development agenda. The aforementioned programmes are implemented through service points that interface with girls/women with $\mathrm{FGM} / \mathrm{C}$ who require interventions such as $\mathrm{FGM} / \mathrm{C}$ message sharing, counselling, and physical medical-surgical procedures. Additionally, 
ongoing programmes such as the Beyond Zero Campaign have infrastructure such as ambulances and supplies for responding to maternal/child challenges that could be leveraged as a platform to roll out anti-FGM/C interventions in Kenya. Indeed, the Beyond Zero programme is well spread across the 47 counties and enjoys a lot of political good will in can leverage, including fundraising.

\section{Limitations}

The desk review provides substantial evidence on the comprehensiveness of FGM/C components on prevention and response to $\mathrm{FGM} / \mathrm{C}$ addressed in nationwide and relevant health sector legal and policy documents in Kenya and Nigeria. Of note is that FGM/C strategies are integrated into either the nationwide FGM/C-related policies or specific health sector policies such as the ASRH policy. However, evidence from field studies on medicalisation and the health system's response to $\mathrm{FGM} / \mathrm{C}$ shows that $\mathrm{FGM} / \mathrm{C}$ interventions are not integrated into existing health programmes. This is a clear indication of non-implementation of the policies, possibly because of a lack of updated national plans of actions that would unlock the required resources to facilitate implementation. Additional research would need to be conducted to establish what it will take to implement the already well articulated policies in the health sector.

\section{Conclusion}

The analyses show that although Kenya and Nigeria have some similarities and differences in legal-governance structures, both have comprehensive nationwide and health sector-specific legal and policy frameworks that integrate prevention and response to FGM/C. Indeed, the content on prevention and response to $\mathrm{FGM} / \mathrm{C}$ is integrated into the policy instruments with provisions and strategies that should guide the health sector's response. However, the corresponding plans of actions, guidelines, and tools of the policies are either outdated, obsolete, or missing, potentially rendering the policies ineffective in harnessing the health sector potential to adequately prevent or respond to management of $\mathrm{FGM} / \mathrm{C}$. The aforementioned gaps are reflected in the findings from field studies involving medicalistaion and health system response to FGM/C studies that show $\mathrm{FGM} / \mathrm{C}$ is not integrated in existing health programmes nor documented, as well as lack of guidelines to support health providers offering prevention and care services to women with complications.

The review highlights components in the policy environments that should be leveraged to promote prevention and response to $\mathrm{FGM} / \mathrm{C}$. These include: commitment from the governments; existence of national and subnational legal-governance structures; existence of a central anti-FGM/C coordinating body; potential for localised/autonomous decision-making; integrated policy and plans of action; high turnover/development of the legal/policy documents; reference to the existing legal/policy documents; availability of high-level policy leadership; and existing opportunities for integration of $\mathrm{FGM} / \mathrm{C}$. The findings underscore the need to rally the health sector to keep fidelity with the policy provisions and strategies on addressing $\mathrm{FGM} / \mathrm{C}$, including working with nationwide FGM/C-response stakeholders. There is need for integration of FGM/C into existing health programmes, while collaboration and partnership in all governance levels is critical. 


\section{Implications for Policy/Programmes/Research}

The study findings highlight several possible avenues for leveraging positive change:

\section{Programmatic implications}

Conducting professional dialogues in Kenya and Nigeria: There is high medicalisation in both countries despite health workers' awareness of the unlawfulness and unethical nature of FGM/C. Interventions involving professionals could include dialogues and training to shift norms. Trainings should address the health impacts of FGM/C, the law, and policies available for facilitating health sector response to the management and prevention of $\mathrm{FGM} / \mathrm{C}$ including medicalisation. The interventions should be implemented through involvement of professional regulatory bodies and associations as a mechanism for reinvigorating professional self-regulation, re-emphasis on the "Do No Harm" principle and development of disciplinary procedures.

Leveraging existing health programmes for integration of FGM/C in Kenya: The Kenya health sector has ongoing programmes including maternal and child health, nutrition, and school health. These are implemented through service points that interface with girls/women with FGM/C who require interventions such as FGM/C message sharing, counselling, and physical medical-surgical procedures. FGM/C could be integrated into highly rated nationwide programmes, notably the Beyond Zero Campaign, that have the resources to address maternal and child health challenges and could be leveraged for anti-FGM/C interventions in Kenya.

Ensuring stakeholder engagement/involvement in Kenya: The Kenyan constitutional dispensation puts a premium on stakeholder engagement and citizen participation in developmental agenda-setting. Devolved governance presents an opportunity through citizen/stakeholders' engagement and participation for identification of priority county programmes. Challenges like FGM/C could be identified because of their health and human rights impacts to find their way onto the policy table. Meaningful engagement will involve county-level synthesis of FGM/C-related evidence. This calls for training CBOs to view FGM/C as a health, social, and human rights problem that the government needs to address.

\section{Policy implications}

Establishment of designated county anti-FGM board champions in Kenya: The recently developed and approved national policy on eradication of FGM/C in Kenya provides for designated anti-FGM/C board representatives in the counties. This should be implemented especially in the high FGM/C-prevalence counties.

Explore adaptation of integrated policy and plans of action in Kenya and Nigeria: A gap in the Kenyan health sector's policies and related earlier policies developed in Nigeria showed wellarticulated policies that nevertheless lacked national plans of action. This could have a negative implication on policy implementation, a fact confirmed through field studies that show a lack of awareness and dissemination. An integrated policy from Nigeria gives an example of how policies and plans of action can be developed simultaneously.

\section{Research implications}

Conduct health systems research to inform the implementation of FGM/C-related laws, policies, and guidelines: Research is needed to stimulate the health sector to implement FGM/C components on prevention and response to management of FGM/C that are well articulated in the specific health sector and nationwide legal/policy documents. Findings from such research will help identify solutions that can strengthen the health sector's response to FGM/C, guide the development of effective health systems-focused FGM/C abandonment interventions, and cultivate collaboration and partnership with other sectors. 


\section{References}

28TooMany. 2018a. "Kenya: The Law and FGM." May: 1-16.

2018b. "Nigeria: The Law and FGM." June: 10. available at:

https://www.28toomany.org/static/media/uploads/Law

Reports/nigeria_law_report_v1_(june_2018).pdf

Dirisu, O., A. Adetunji, M. Adediran, and O. Obianwo. 2020. "A diagnostic assessment of health system response to FGM/C management and prevention in Nigeria." Evidence to End FGM/C: Research to Help Girls and Women Thrive. Nairobi: Population Council.

Federal Government of Nigeria. 2015. Violence Against Persons (Prohibition) Act. Abuja: Federal Parliament of Nigeria.

Federal Ministry of Health (FMOH), Nigeria. 2013. National Policy and Plan of Action for Elimination of Female Genital Mutilation in Nigeria 2013-2017. Abuja; FMOH. 2017. National Reproductive Health Policy. Abuja: FMOH.

Government of Kenya. 2010. The Constitution of Kenya, 2010. Kenya Law Reports (February):

31. Available at: www.kenyalaw.org

2011. Nurses Amendment Act 2011. Cap 257. Nairobi.

2012. Medical and Dentists Act. Cap 253, 36 § (2012). Nairobi.

2017. Clinical Officers Act. CBPR Database - Kenya. Nairobi.

https://doi.org/10.1017/S0022278X00014853

Kenya Law. 2015. "The Protection Against Domestic Violence Act," Kenya Gazette 13-38.

Available at:

http://kenyalaw.org/kl/fileadmin/pdfdownloads/Acts/ProtectionAgainstDomesticViolenceAct_ 2015.pdf

Kimani, S. and C. Okondo. 2020. A Diagnostic Assesment of Health Systems Response to Management and Prevention in Kenya. Nairobi: Population Council. Evidence to End FGM/C: Research to Help Girls and Women Thrive. New York: Population Council.

Laws of Kenya. 2001. Children Act c.31. Kenya: Kenya Law Reports. Available at:

http://www.kenyalaw.org

2012. Penal Code Chapter 63, 1. Available at: www.kenyalaw.org

Ministry of Education (MOE), Kenya. 2018. National School Heath Policy. Nairobi: MOE.

Ministry of Gender Affairs, Kenya. 2019. National Policy on Eradication of Female Genital Mutilation. Nairobi: Government of Kenya.

Ministry of Health, Kenya. 2007. Management of Complications Pregnancy, Childbirth and the Postpartum Period in the Presence of FGM/C. Nairobi: Ministry of Health.

2015. National Adolescent Secual and Reprodutcive Health Policy. Nairobi: Government of Kenya.

Ministry of Public Health and Sanitation and Ministry of Education. 2015. National School Health Strategy Implementation Plan. Nairobi: Government of Kenya

National Council for Law Reporting. 2011. Prohibition of Female Genital Mutilation Act, (32): 514. Available at:

http://kenyalaw.org/kl/fileadmin/pdfdownloads/Acts/ProhibitionofFemaleGenitalMutilationAct No32of2011.pdf

National Plan of Action for Children in Kenya 2015-2022. 2015. Nairobi: Government of Kenya. Nigeria, Federal Government of. 1999. The Constitution of the Federal Republic of Nigeria. Abuja: Federal Parliament of Nigeria. Available at: http://www.nigerialaw.org/ConstitutionOfTheFederalRepublicOfNigeria.htm

Walt, G. and L. Gilson. 1994. "Reforming the health sector in developing countries: The central role of policy analysis," Health Policy and Planning. https://doi.org/10.1093/heapol/9.4.353 
Attachment: Female Genital Mutilation/Cutting: A Review of Laws and Policies in Kenya and Nigeria Report Appendices 